\title{
Beniamin Noga*
}

Marian Noga**

Wyższa Szkoła Bankowa we Wrocławiu

\section{EDUKACJA EKONOMICZNA SPOŁECZEŃSTWA A EDUKACJA PRZEDSIĘBIORCZOŚCI}

\begin{abstract}
STRESZCZENIE
Celem opracowania jest określenie edukacji przedsiębiorczości jako kategorii naukowej, która jest elementem edukacji ekonomicznej. Jest to niezwykle ważne dla polskiej gospodarki, gdyż aby myśleć o szybkim doganianiu państw wysokorozwiniętych, przede wszystkim w zakresie uzyskiwanych dochodów i wysokiego PKB na 1 mieszkańca, musimy stworzyć silną i pojemną klasę średnią, a bez wzrostu przedsiębiorczości nie będzie to możliwe.
\end{abstract}

Słowa kluczowe: edukacja przedsiębiorczości, edukacja ekonomiczna

\section{Wprowadzenie}

Stan wiedzy i świadomości ekonomicznej Polaków jest wysoce niesatysfakcjonujący. Brakuje zarówno wiedzy o:

- prawach ekonomicznych i ich charakterze,

* E-mail: marian.noga@wsb.wroclaw.pl

** E-mail: agata.bzura@wsb.wroclaw.pl 
- cyklicznym rozwoju gospodarki rynkowej i nieuchronności kryzysów gospodarczych,

- ryzykach różnego rodzaju, związanych praktycznie z każdą decyzją gospodarczą,

- instytucjach i praktycznych umiejętnościach korzystania z instrumentów finansowych,

- związkach ekonomii z kulturą, polityką, etyką, socjologią i innymi naukami, jak i wiedzy z zakresu makroekonomii i powiązania gospodarki krajowej z gospodarką globalną. Dzisiaj w gospodarce mamy do czynienia z połączeniem ryzyka gospodarczego z ryzykiem politycznym, co nazywamy ryzykiem systemowym państwa. S. Hoti (2002, s. 1-61) słusznie stwierdza, że dla określenia ryzyka systemowego danego państwa, fundamentalne znaczenie mają trzy czynniki:

- ekonomiczne - PKB per capita, roczna stopa inflacji, stopa realnego wzrostu PKB, udział deficytu budżetu państwa w PKB danego roku, deficyt obrotów bieżących handlu zagranicznego w stosunku do PKB (\%),

- finansowe - zadłużenie zagraniczne do PKB (\%), stabilność kursu walutowego, obsługa zadłużenia zagranicznego (\% PKB), płynność netto oraz bilans handlowy jako procentowy udział w eksporcie,

- polityczne - stabilność rządu, konflikty wewnętrzne i zewnętrzne, warunki socjoekonomiczne, profil inwestycyjny, obecność wojska w polityce, korupcja, napięcia etniczne oraz religijne, poziom demokracji, poziom biurokracji, porządek prawny.

Narodowy Bank Polski w Strategii edukacji ekonomicznej NBP na lata 2010 2012 stwierdza, że bez świadomego ekonomicznie i finansowo społeczeństwa nie jest możliwy stabilny wzrost gospodarczy. Istotnym zagrożeniem dla stabilnego wzrostu są:

- stereotypy,

- mity,

- błędne przekonania dotyczące zagadnień ekonomicznych (Strategia...)

Ponadto NBP stwierdza, że istnieje silna korelacja między jakością edukacji ekonomicznej a rozwojem gospodarczym. Powyższe rozważanie pokazuje wręcz, że rozwój gospodarczy zależy od edukacji ekonomicznej społeczeństwa. Zatem - czym jest edukacja ekonomiczna? Zacznijmy od wyjaśnienia genezy słowa „edukacja”, które wywodzi się od łacińskiego „educatio” - wychowanie, wykształcenie, kształcenie. 
Cicero używał łacińskiego „educatio” w rozumieniu „wychowanie”. Jak słusznie pisze się w literaturze przedmiotu, termin edukacja jest dosyć chwiejny, bowiem jedni kojarzyli go z wykształceniem, a inni z wychowaniem. Ale tak już było w starożytnym Rzymie. Jak słusznie pisze Mirosław Bańko (2000, s. 365) „,edukacja to słowo książkowe, a oznacza «uczenie kogoś lub uczenie się, zwłaszcza instytucjonalne, np. w szkole» lub «kształtowanie u kogoś określonych postaw lub reakcji»». Pedagodzy z kolei w terminie „edukacja” widzą przede wszystkim zmienianie ludzi, szczególnie dzieci i młodzieży, stosownie do panujących w danym społeczeństwie ideałów i celów wychowawczych w sposób instytucjonalny, np. w szkole (por. Okoń, 1987, s. 66).

Jak słusznie zauważa A. Jeżowski, edukacja we współczesnym świecie nabiera zupełnie nowego znaczenia, bowiem edukacja to „zorganizowany przez państwo system nauczania i wychowania, ale skoncentrowany na rozwoju społeczeństwa, a co zatem idzie, także na jego rozwoju gospodarczym (Jeżowski, 2007, s. 12).

W 1998 roku opracowany został Raport dla UNESCO przez Międzynarodową Komisję do Edukacji dla XXI wieku, którego autorem był Jacques Delors, w którym napisano: „w obliczu wyzwań, edukacja jawi się jako szansa, którą należy bezwzględnie wykorzystać w dążeniu ludzkości do ideałów pokoju wolności i sprawiedliwości społecznej (...). Komisja marzy o edukacji twórczej i budującej nowego ducha. Mimo to nie zaniedbała trzech pozostałych filarów edukacji, które w pewnym sensie dostarczają podstawowej wiedzy, jak uczyć się, aby żyć wspólnie. Przede wszystkim - uczyć się, aby wiedzieć (...) Uczyć się, aby działać (...) Uczyć się, aby być - wreszcie i przede wszystkim (...) Tak więc edukacja powinna stale przystosowywać się do zmian społecznych, nie zaniedbując przekazywania osiągnięć, podstaw i rezultatów ludzkiego doświadczenia" (Raport..., s. 9-19). W tym miejscu należy mocno podkreślić, że wymieniony Raport stwierdza, że aby edukacja zapewniła wysoką jakość kształcenia i sprawiedliwość społeczną, musi mieć charakter edukacji ustawicznej.

\section{Edukacja ekonomiczna}

Analiza dotycząca zagadnienia edukacji w ogóle pozwala nam zdefiniować własną definicję edukacji. Brzmi ona następująco:

Edukacja jest to ogół czynności i procesów mających na celu uczenie, czyli przekazywanie wiedzy i umiejętności korzystania z dorobku i doświadczenia ludz- 
kości; uczenie się wszystkiego, co pozwala żyć wspólnie oraz kształtowanie określonych cech i umiejętności w procesie wychowania i zmieniania ludzi, szczególnie ludzi młodych w sposób instytucjonalny i spersonalizowany, pozainstytucjonalny.

Jest to nasza definicja edukacji, która ma roboczy i opisowy charakter, ale na pewno ułatwi nam dobre określenie edukacji ekonomicznej. Edukacja ekonomiczna jest to po prostu uczenie (kogoś) i uczenie się (samemu) ekonomii i wszystkich jej dziedzin, takich jak:

- finanse,

- ekonomiki branżowe,

- historia gospodarcza,

- statystyka ekonomiczna i ekonometria,

- zarządzanie w teorii i praktyce,

- matematyka finansowa,

- teoria podejmowania decyzji ekonomicznych z wykorzystaniem narzędzi matematyki, takich jak teoria gier itp.

Oczywiście jest to punkt wyjścia do definiowania edukacji ekonomicznej. Edukację ekonomiczną możemy więc określić jako proces uczenia i uczenia się ekonomii i wszystkich jej dyscyplin, posługiwanie się wiedzą uzyskaną w procesie nauczania w praktyce gospodarczej oraz kształtowanie świadomości i wyobraźni ekonomicznej niezbędnej do funkcjonowania w warunkach gospodarki rynkowej powszechnie panującej w skali globalnej.

Tak określona przez nas edukacja ekonomiczna wyraźnie dzieli się na:

- edukację finansową (bankową i ubezpieczeniową),

- edukację przedsiębiorczości,

- edukację konsumencką,

- edukację makroekonomiczną kształtująca świadomość ekonomiczną opartą na relacjach mikropodmiotów gospodarczych z otoczeniem bliższym i dalszym, instytucjonalnym i pozainstytucjonalnym składającym się na ład gospodarczy (ekonomiczny) i ład społeczny.

Obecnie przechodzimy do analizy, kluczowej części edukacji ekonomicznej, czyli edukacji przedsiębiorczości. 


\section{Edukacja przedsiębiorczości}

Kreatywność, innowacyjność i przedsiębiorczość to trzy składowe budowania silnej, nowoczesnej gospodarki rynkowej, czyli takiej, jaką chcemy stworzyć w Polsce. W tym miejscu chcielibyśmy wyjaśnić, jak należy podchodzić do analizy przedsiębiorczości, i odpowiedzi na pytanie, co to jest „przedsiębiorczość”. Wydaje się, że roboczo przedsiębiorczość można określić jako: „cecha działania zmierzającego do zapewnienia racjonalnej i efektywnej koordynacji zasobów, jako swoista forma pracy lub jako czwarty czynnik produkcji, po pracy, ziemi i kapitale" (Bratnicki, Strużyna, 2001, s. 34). Natomiast w aspekcie ekonomicznym, najbardziej klarowną definicję przedsiębiorczości prezentują S. Shane i S .Ventakataraman (Shane, 2003, s. 3-5), pisząc że „są to wszelkie działania, na które składają się identyfikacja, ocena i eksploatacja szans wprowadzenia nowych produktów i nowych usług, czy też sposobów organizowania nowych rynków, nowych surowców (...). W przedsiębiorczości zawsze występują takie elementy, jak:

- istnienie szans rynkowych jako warunek sine qua non,

- ponoszenie ryzyka,

- występowanie różnych opcji w rozpoznaniu szans rynkowych,

- tworzeniu nowych kombinacji zasobów,

- wprowadzanie innowacji, niekoniecznie o charakterze przełomowym".

O przedsiębiorczości można również mówić jako o postawie i zachowaniu się przedsiębiorcy, czyli słynnego entrepreneura, jako jego zespole cech działania i charakteru. W końcu o przedsiębiorczości można mówić jako o procesie z jednej strony i zespole cech opiniujących sposób postępowania człowieka z drugiej strony. Oczywiście proces to działania ukierunkowane na wprowadzenie produkcji i sprzedaży nowatorskiego pomysłu, a zespół cech to kreatywność, skłonność do ryzyka, dynamizm, przestrzeganie szans i umiejętność przystosowania się do zmieniających się warunków (Shane, 2003, s. 3-5).

W tym miejscu chcielibyśmy wskazać na burzliwy rozwój teorii przedsiębiorczości, przy czym - co zauważyliśmy w literaturze przedmiotu - tak naprawdę każdy uczony miał swoją teorię przedsiębiorczości. Pionierami na pewno byli Frank H. Knight i Jospeh A. Schumpeter. Potem pojawiły się nowe spojrzenia na przedsiębiorczość, których autorami są: H.B. Hostelitz, A. Cole, D. Mc Clelland, M. Casson, W.B. Gartner, H.H. Stevenson, M.J. Roberts, H.I. Grousbeck, M.M. Hart, J. Dail, 
P. Drucker, bądź spojrzenia współczesnych przedsiębiorców, takich jak Lee Iacocca, Henry Ford, Dave Gibbons, Steve Jobs, Bil Gates, Warren Buffet, Steve Wozniak i inni, jak chociażby Karol Marks. Ale do przedsiębiorczości można też podchodzić w sposób zupełnie nieoczekiwany, tak jak Kamil Janus, który uważa, że przedsiębiorczość to poszukiwanie nowoczesnych doznań za pośrednictwem książek filozoficzno-kulturowych. Również przedsiębiorczość to gry i zabawy polegające na biegłym rachunku matematyczno-fizycznym (Hasło Przedsiębiorczość).

Wydaje się, że obecnie już wiemy, co to jest przedsiębiorczość i w tym momencie przystępujemy do wyjaśnienia: co to takiego jest edukacja przedsiębiorczości? I tutaj od razu napotykamy na kilkanaście mitów związanych z przedsiębiorczością, z których ten najbardziej rozpowszechniony to taki, że przedsiębiorcą trzeba się urodzić, a więc zachowań przedsiębiorczych nie można się nauczyć (Bratnicki, Dyduch, Gabryś). Jest to typowy stereotyp, który trzeba eliminować z życia społecznego, tak jak stereotyp, że nie można nauczyć się dobrze ekonomii. Bardzo trafną wydaje się tutaj anegdotyczna odpowiedź na pytanie: Co to jest ekonomia? Jest to prosty, chłopski rozum podany w zawiłej formie. Albo bardziej nobliwe, jest to common sense podany w zawiłej formie! Współczesne badania światowe (S. Cummings, J. Roure, D.F. Kuratko, S. Birley, D.F. Muzyka, J.A. Timmons) i polskie, np. profesora Mariusza Bratnickiego, pokazują, że każdy człowiek ma potencjał zostania przedsiębiorcą poprzez nabywanie odpowiednich umiejętności, wiedzy, doświadczenia, a także poprzez nawiązywanie bezpośrednich kontaktów (Bratnicki, Dyduch, Gabryś).

Bratnicki, Dyduch i Gabryś, obok mitu o tym, że trzeba urodzić się przedsiębiorcą i że przedsiębiorczości nie można się nauczyć, wymieniają jeszcze 10 mitów hamowania przedsiębiorczości z pozycji przedsiębiorcy, 11 mitów z punktu widzenia działalności przedsiębiorczej i 8 mitów z punktu widzenia organizacji przedsiębiorczej. Gdyby w tym momencie należało formułować definicję edukacji przedsiębiorczości, to jednym z jej kanałów byłoby eliminowanie tych 29 mitów i przekształcenie poglądów blokujących przedsiębiorczość w działania pobudzające przedsiębiorczość.

Przedsiębiorczość jest wpisana w rzeczywistość ludzkiego działania, co wynika z dynamiki zmian otoczenia działalności gospodarczej. Dlatego też w praktyce gospodarczej i społecznej możemy mówić o następujących typach przedsiębiorczości:

- przedsiębiorczość indywidualna (własna), obejmująca działania konkretnej osoby, 
- przedsiębiorczość małego biznesu dotycząca tworzenia i prowadzenia małych firm,

- przedsiębiorczość gospodarczych systemów zorganizowanych,

- przedsiębiorczość w administracji rządowej i lokalnej,

- przedsiębiorczość w sektorze organizacji społecznych (non-profit),

- przedsiębiorczość międzynarodowa (Antoszkiewicz, 2013, s. 13).

Powyższa enumeracja typów przedsiębiorczości obala kolejny mit, że przedsiębiorczość dotyczy tylko sektora prywatnej działalności produkcyjnej i usługowej. Jakże słuszny jest tytuł tomu, z którego zaczerpnięto tę enumerację typów przedsiębiorczości - Przedsiębiorczość: szansa na sukces rządu, gospodarki, przedsiębiorstw, społeczeństwa. Szkoda, że rządzący tego nie rozumieją i poprzez nieprzemyślane regulacje hamują dopływ do sektora administracji rządowej i lokalnej, a także do publicznych spółek, ludzi przedsiębiorczych, np. poprzez ustalanie 70\% podatku od praw w związku ze zwolnieniem stanowiska. Jest to działanie szkodzące podstawowym interesom całego społeczeństwa.

Sięgnijmy jeszcze raz do początków rozważań - w literaturze przedmiotu o przedsiębiorczości. J.K. Solarz stwierdza, że do obiegu naukowego „przedsiębiorczość" wprowadzili dwaj francuzi: Bernard F. de Bolidon i Jean-Babtiste Say. Pierwszy z nich jako przedsiębiorczego określił takiego kupca, który kupuje pracę i materiały po niepewnej, zmiennej cenie i sprzedaje ich rezultat (produkt), po wcześniej określonej cenie. Drugi za przedsiębiorcę uważał tego, który inwestował swoje dzisiejsze zasoby w nieznaną i nierozpoznawalną przyszłość. Oba te określenia wiązały przedsiębiorczość z zarządzaniem ryzykiem. Joseph Schumpeter stworzył koncepcję przedsiębiorcy jako spoiwo wynalazcy i bankiera i dla niego w ujęciu teoretycznym to taki podmiot gospodarczy, który aktywnie realizuje nową kombinację czynników produkcji. Ten teoretyczny model przedsiębiorczości z początku XX wieku stał się faktem społecznym o doniosłym znaczeniu na początku XXI wieku, gdzie obserwujemy dyfuzję przedsiębiorczości, jako motoru napędowego rozwoju gospodarczego (Solarz).

J.K. Solarz uważa, że ta definicja ma przede wszystkim trzy przyczyny:

- profesjonalizacja tworzenia i realizacji innowacji,

- upowszechnienie i umiędzynarodowienie profesjonalnego pośrednictwa finansowego,

- oparcie rozwoju gospodarczego na wiedzy (Gospodarka Oparta na Wiedzy - GOW). 
Ciekawą inicjatywę podjął Narodowy Bank Polski realizując zakrojone na szeroką skalę badania, szeroko rozpowszechniane, w zakresie kształtowania postaw przedsiębiorczych. W wyniku tych badań określono tzw. orientację na przedsiębiorczość, która obejmuje:

- autonomię,

- innowacyjność,

- skłonność do podejmowania ryzyka,

- aktywność,

- konkurencyjność,

- wytrwałość,

- wiarę we własne możliwości,

- pracowitość (Edukacja...).

W tym kontekście Komisja Europejska wskazuje na dwa możliwe podejścia do kształtowania postaw przedsiębiorczych i edukacji przedsiębiorczości:

- szerszą, opartą o kształtowanie zachowań i umiejętności, wynikającą z cech osobowych,

- węższą, dotyczącą formalnego procesu nauczania, jak zakładać i prowadzić własną działalność (Edukacja...).

Edukacja szkolna w zakresie przedsiębiorczości powinna uwzględniać:

- rozwój przedsiębiorczych cech osobowości uczniów,

- kontakty z lokalnymi przedsiębiorcami - case study,

- planowanie kariery z uwzględnieniem możliwości samozatrudnienia,

- learning by doing,

- szkolenia dotyczące własnej firmy.

Pobudzanie przedsiębiorczości wśród studentów powinno obejmować:

- obowiązkowe uczestnictwo w realizowaniu zadań o charakterze projektowym,

- stworzenie możliwości samodzielnego rozwiązywania zadań z różnych dziedzin,

- pielęgnowanie tradycyjnej, akademickiej niezależności w myśleniu i rozwiązywaniu problemów,

- tworzenie w uczelniach Biur Karier,

- tworzenie Instytutów Współpracy z Biznesem,

- udział top managementu średnich i dużych firm w Radach Wydziału, w Radach Biznesu realizowanych kierunków kształcenia, 
- tworzenie start-upów,

- tworzenie spin-offów,

- tworzenie spin-outów,

- tworzenie Akademickich Inkubatorów Przedsiębiorczości.

Również w przedszkolach edukacja przedsiębiorczości powinna odbywać się w postaci zabawowej. Powinny się na przykład pisać specjalne wiersze, bajki, opowiadania, sztuki teatralne o przedsiębiorczości trafiające do wyobraźni 4-6-latka. Społeczeństwo, w którym dominuje gospodarka rynkowa, państwo prawa jest państwem równości szans, a nie równości dochodów czy majątku. Stąd już przedszkolaków należy przygotowywać, jak zdobyć wiedzę, umiejętności, będące później fundamentem życia wspólnego w społeczeństwie. To jest równość szans, a nie kształtowanie postaw roszczeniowych.

Obecnie przechodzimy do sformułowania własnej definicji edukacji przedsiębiorczości. Oto krótki przegląd tej kategorii w literaturze przedmiotu:

1. I. Jamieson (1984) wprowadza trzy kategorie edukacji przedsiębiorczości:

a) edukacja o przedsiębiorczości (education about enterprises),

b) edukacja dla przedsiębiorczości (education for enterprises),

c) edukacja przez przedsiębiorczość (education in enterprises).

2. J. Guzman i F. Liñan (2005) wprowadzają cztery kategorie edukacji na rzecz przedsiębiorczości:

a) edukacja w zakresie promowania własnej działalności gospodarczej albo alternatywnej ścieżki kariery zawodowej;

b) edukacja $\mathrm{w}$ zakresie uruchomienia działalności gospodarczej w fazie start-up;

c) edukacja dokształcająca skierowana dla dojrzałych przedsiębiorców;

d) edukacja w zakresie przedsiębiorczego dynamizmu promująca przedsiębiorcze postawy, takie jak:

- kreatywność,

- innowacyjność,

- inwencyjność,

- własną inicjatywę w miejscu pracy,

- własną inicjatywę we własnym biznesie. 
3. Brytyjska Agencja Zapewnienia Jakości w Szkolnictwie Wyższym QAA (2012) definiuje edukację w zakresie przedsiębiorczych przedsięwzięć (enterprises education) jako proces wyposażenia uczniów i/lub studentów (względnie absolwentów) w bogate zdolności do generowanie pomysłów (Wach).

Można stwierdzić, że edukacja przedsiębiorczości obejmuje te dziewięć propozycji zaprezentowanych w literaturze przedmiotu. Ale naszym zdaniem nawet one nie obejmują wszystkich aspektów procesu edukacji przedsiębiorczości. Stąd nasza autorska definicja edukacji przedsiębiorczości brzmi następująco:

Edukacja przedsiębiorczości to ciągły proces nauczania i uczenia się całego społeczeństwa, pracującego lub przygotowującego się do podjęcia pracy we wszystkich sektorach gospodarki, proces wyposażający w odpowiednią wiedzę o mechanizmach gospodarczych, proces kształtowania postaw przedsiębiorczych i wiedzy o ryzyku mikroekonomicznym i ryzyku systemowym, proces przygotowywania do podejmowania efektywnych decyzji w zmieniającym się otoczeniu zewnętrznym.

\section{Podsumowanie}

Przedstawione w artykule rozważania i analizy kategorii naukowej edukacji przedsiębiorczości upoważniają nas do wysunięcia następujących konkluzji:

Budowa w Polsce nowoczesnej gospodarki o dużych dochodach społeczeństwa wymaga przede wszystkim stworzenia silnej klasy średniej, stanowiącej trzon społeczeństwa.

Edukacja przedsiębiorczości jest „kluczem” do zbudowania silnej gospodarki, co pokazała historia gospodarcza świata. Dlatego edukacja przedsiębiorczości powinna być w Polsce przeorientowana, chociażby w taki sposób, jak pokazaliśmy w tym artykule.

\section{Literatura}

Antoszkiewicz, J.D. (2013). Rozwijanie przedsiębiorczości - wybrane koncepcje. W: K. Piech, M. Kulikowski (red.), Przedsiębiorczość: szansa na sukces rzadu, gospodarki, przedsiębiorstw, społeczeństwa. Warszawa: Instytut Wiedzy.

Bańko, M. (red.) (2000). Inny stownik języka polskiego. T. 1. Warszawa: Wydawnictwo Naukowe PWN. 
Bratnicki, M. Dyduch, W., Gabryś, B.J. Mity przedsiębiorczości w polskich organizacjach: diagnoza i mechanizmy ożywiania potencjału przedsiębiorczości. Pobrano z: www.fundacja.edu.pl/przedsiebiorczosc/_referaty/sesja_IV/34.pdf.

Bratnicki, M. Strużyna, S. (2001). Przedsiębiorczość i kapitat intelektualny. Katowice: Wydawnictwo Akademii Ekonomicznej w Katowicach.

Edukacja ekonomiczna a ksztattowanie postaw przedsiębiorczych. Pobrano z: file://c:/Users/wsb/Downloads/Edukacja_ekonomiczna_postaw_przedsiębiorczych\%20(1).pdf (26.12.2015).

Hasło Przedsiębiorczość. Pobrano z: https://pl.wikipedia.org/wiki/Przedsiębiorczość (25.12.2015).

Hoti, S. (2002). Country risk rating - an international comparison. Perth: University of Western Australia.

Jeżowski, A. (2007). Ekonomiczne determinanty efektywności w edukacji (wybrane zagadnienia). Głogów: Państwowa Wyższa Szkoła Zawodowa w Głogowie.

Okoń, W. (1987). Słownik pedagogiczny. Warszawa: PWN.

Raport dla UNESCO Międzynarodowej Komisji ds. Edukacji dla XXI wieku (1998). Edukacja, jest w niej ukryty skarb. Warszawa: Stowarzyszenie Oświatowców Polskich Wydawnictwa UNESCO.

Shane, S. (2003). A General Theory of Entrepreneurship, the Invidual - Oportunity Nexus. Northampton: Edward Elgar.

Solarz, J.K. Poznawcze i instytucjonalne bariery przedsiębiorczości w Polsce. W: P. Wachowiak, M. Dąbrowski, B Majewski. Ksztattowanie postaw przedsiębiorczych a edukacja ekonomiczna. Pobrano z: file://c:/users/wsb/deskop/przedsiębiorczośćFPAKE_ publikacje.pdf (26.12.2015).

Strategia edukacji ekonomicznej NBP na lata 2010-2012. NBP: Wydział Wydawnictw.

Wach, K. Edukacja na rzecz przedsiębiorczości wobec współczesnych wyzwań cywilizacyjno-gospodarczych. Pobrano z: file:///c:/Users/wsb/Desktop/133-3939-1-PB.pdf (26.12.2015). 


\title{
ECONOMIC EDUCATION OF SOCIETY VS ENTERPRISES EDUCATION
}

\begin{abstract}
In the paper, authors have presented new point of view on enterprises education in Polish economy. Enterprises education is analysis in the light of economic education. Paper has most impotent conclusions for building middle class in Poland.
\end{abstract}

Keyword: enterprises education, economic education

Kod JEL: A23 